\title{
短報
}

\section{青森県周辺海域におけるキアンコウの 瘤状鼻管幅の性差}

竹谷裕平, $1,2 *$ 高津哲也, ${ }^{3}$ 山中智之, $1 \mathrm{a}$ 柴田泰宙, 4 中屋光裕 5

(2017 年 5 月 14 日受付, 2017 年 8 月 27 日受理, 2017 年 12 月 6 日 J-STAGE 早期公開)

1(地独)青森県産業技術センター水産総合研究所,

2 北海道大学大学院水産科学院,

3 北海道大学大学院水産科学研究院,

${ }^{4}$ (国研) 水産研究 - 教育機構東北区水産研究所, ${ }^{5}$ 北海道大学水産学部

Sexual dimorphism in the size of bulbous nasal tubes of yellow goosefish Lophius litulon off

Aomori Prefecture, northern Japan

YuHeI TAKEYA, ${ }^{1,2 *}$ Tetsuya TAKATSU, ${ }^{3}$

TOMOYUKI YAMANAKA, ${ }^{\text {1a }}$ YASUTOKI SHIBATA ${ }^{4}$

AND MitsuHIRo NAKAYA ${ }^{5}$

${ }^{1}$ Aomori Prefectural Industrial Technology Research Center Fisheries Institute, Hiranai, Aomori 039-3381, ${ }^{2}$ Graduate School of Fisheries Sciences, Hokkaido University, Hakodate, Hokkaido 041-8611, ${ }^{3}$ Faculty of Fisheries Sciences, Hokkaido University, Hakodate, Hokkaido 0418611, "Tohoku National Fisheries Research Institute, Japan Fisheries Research and Education Agency, Hachinohe, Aomori 031-0841, ${ }^{5}$ Faculty of Fisheries, Hokkaido University, Hakodate, Hokkaido 041-8611, Japan

キーワード : キアンコウ, 性的二型, 性判別, 瘤状鼻管 幅

キアンコウ Lophius litulon は日本周辺海域に広く分 布し, 主に底曳網漁業の重要な漁獲対象種である。著者 らが主要水揚港を対象として調査したアンコウ類の漁獲 量は近年全国的に減少傾向にあり, 青森県でも 2009 年 までの年間 $900 t$ 前後から 2016 年の $353 t$ にまで減少 している (竹谷ら, 未発表)。適切な資源管理の遂行に は, まずその生態や年齢・成長等といった資源特性值を 把握する必要がある。このため著者らは, 青森県周辺海 域のキアンコウについて分布・移動に関する知見を得る ためのディスクタグ装着法やバイオロギング法を用いた 標識放流調查を行った。吕2) また, 非可食部である背鰭 第一棘（誘因突起）を用いた年齢査定法を確立した。3)
ところで本種の成長には雌雄差があることが知られてい るが, ${ }^{4-7)}$ 市場で腹部圧迫やカニュレーション等によっ て雌雄判別を行うと, 本種では肝臓を傷付けて商品価値 を毀損する恐れがあることから, 試料魚を買い上げて解 剖し, 生殖腺を直接観察する必要があった。一方, 本種 を含むアンコウ科の瘤状鼻管は, 雄の方が䧳に比べて相 対的に大きく，性的二型と考えられてきた。8) 外部形態 である瘤状鼻管の体長との相対サイズから正確に雌雄が 判別できるようになれば, 背鰭第一棘による年齢査定 法3)を併用することで, 高価で取引されている本種を買 い上げることなく, 成長解析が可能となる。そこで本研 究は, 青森県周辺の日本海・津軽海峡・太平洋で採集さ れたキアンコウについて, 瘤状鼻管幅と全長の測定によ る性判別法の精度を検証した。また, 漁獲現場の聞き取 りから，この瘤状鼻管サイズの性的二型の果たす生態学 的役割も考察した。

キアンコウ標本は, 2014 年 4 月から 2016 年 12 月ま での期間, 青森県周辺海域の日本海, 津軽海峡, 太平洋 に抢いて, 刺網漁業抢よび底建網漁業, 沖合底电網漁 業, 水産研究 - 教育機構東北区水産研究所漁業調査船 若鷹丸（692 t ）打よび地方独立行政法人青森県産業技 術センター水産総合研究所調查船・青鵬丸 $(65 \mathrm{t})$ によ る着底トロールにより得られた。標本は凍結して研究室 に持ち帰り, 解凍後, 主たる漁獲対象である体重 $1 \mathrm{~kg}$ 以上の雄 266 個体（全長 357-1,005 mm), 雌 377 個体 (全長 356-1,182 mm) について, 全長 (Total length 以下 TL と表記; $1 \mathrm{~mm}$ 単位) の測定と解剖による性判 別を行い, 左右の瘤状鼻管を採集した（Fig. 1)。性判 別は, 解剖して摘出した生殖腺の目視観察で行い, 同属 の Lophius piscatorius を参考 ${ }^{9}$ に, 黄・橙色で帯状の膜 構造内に卵様の粒物質が認められるものを雌, 乳白色で 筒状のものを雄と判定した。瘤状鼻管幅 (The bulbousnasal-tube width 以下 NW と表記, $1 \mu \mathrm{m}$ 単位）は, 実 体顕微鏡に装着したデジタルカメラ（DP21，オリンパ ス株式会社, 東京）で撮影した画像を用いて, 顕微鏡イ メージングソフトウェア(CellSens Standard 1.9, 同上) で測定し, 左右の平均值をその個体の代表值として用い た。全長-瘤状鼻管幅の 1 次回帰式を最小二乗法で求め た。また, 後述する性判別法について, $100 \mathrm{~mm}$ TL 階 級別に正答率, 誤答率, 判別不能率を算出し, 体長階級 の順序を考慮した比率の Kruskal-Wallis 検定で有意差

C) 2018 公益社団法人日本水産学会/The Japanese Society of Fisheries Science

* Tel : +81-17-755-2155. Fax : +81-17-755-2156. Email : yuuhei_takeya@aomori-itc.or.jp

a 現所属：(地独) 大阪府立環境農林水産総合研究所 (Research Institute of Environment, Agriculture and Fisheries, Osaka Prefecture, Misaki, Osaka 599-0311, Japan) 


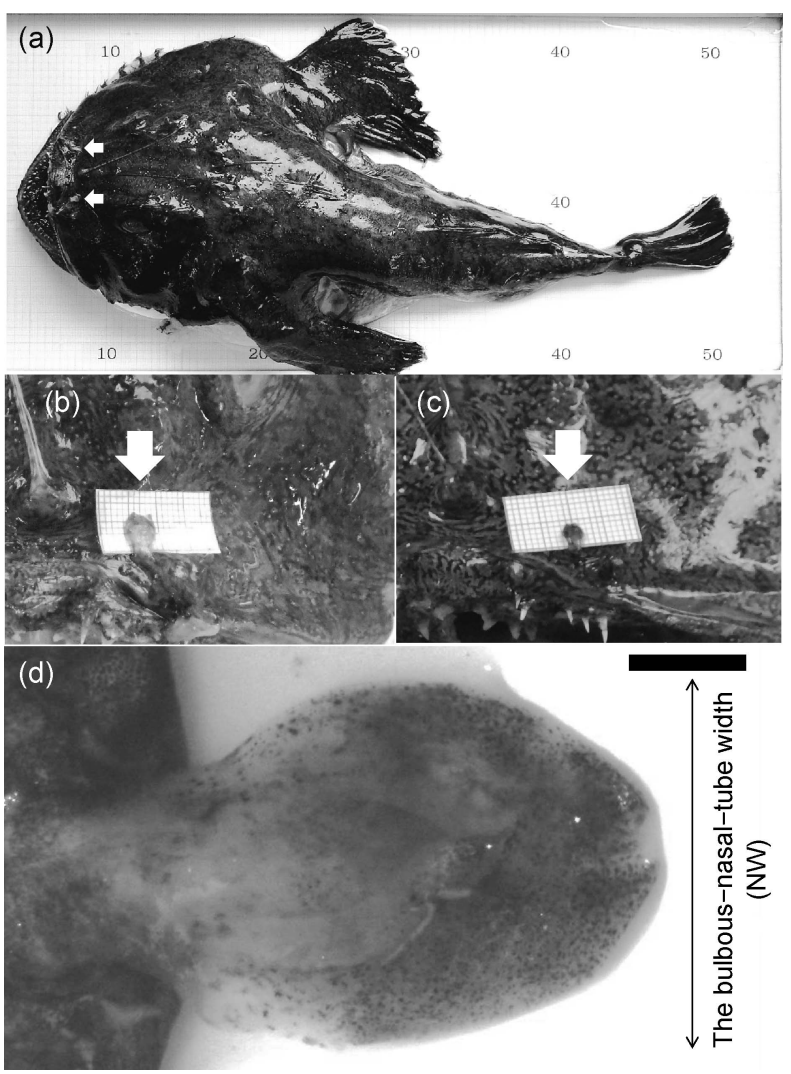

Fig. 1 Photographs of yellow goosefish Lophius litulon: (a) the bulbous nasal tubes placed from anteriorly on the snout lateral to the illicial pterygiophore, $(b, c)$ the bulbous nasal tubes of male $426 \mathrm{~mm}$ TL and female $452 \mathrm{~mm}$ TL on graph paper ruled into $1 \mathrm{~mm}$ squares, respectively, (d) measurement position of the width of the bulbous nasal tubes. Scale bar in (d), 1,000 $\mu \mathrm{m}$.

の有無を検討した。10)

体重 $1 \mathrm{~kg}$ 以上の個体の全長一瘤状鼻管幅間の回帰式 は，以下のように推定された。

雄 : $N W=17.198 T L-2654.530$

$$
\left(n=266, r^{2}=0.757, p<0.001\right)
$$

雌 : $N W=7.131 T L-51.913$

$$
\left(n=377, r^{2}=0.776, p<0.001\right)
$$

得られた回帰式の傾きの間には有意差がみられ（ $F$ 検 定, $p<0.001)$, 瘤状鼻管幅は雌よりも雄の方が大き かった。

これらの回帰式の両側 $\pm 20 \%$ 範囲で偽陰性が存在 すると仮定した場合, 雄回帰式の-20\%下限值と雌回 帰式の+20\% 上限值は, 以下である。

$$
\begin{aligned}
& \text { 雄 }-20 \%: N W=13.758 T L-0.002 \\
& \text { 此 }+20 \%: N W=8.557 T L-0.623
\end{aligned}
$$

ここで，全長に対する瘤状鼻管幅が雄回帰式の-20\% 以上を雄, 雌回帰式の $+20 \%$ 以内を雌, 両者の重複範 囲若しくはいずれにも属さない範囲の個体を判別不能と 仮定し（Fig. 2), 有効性を検証した（Fig. 3)。正答率,

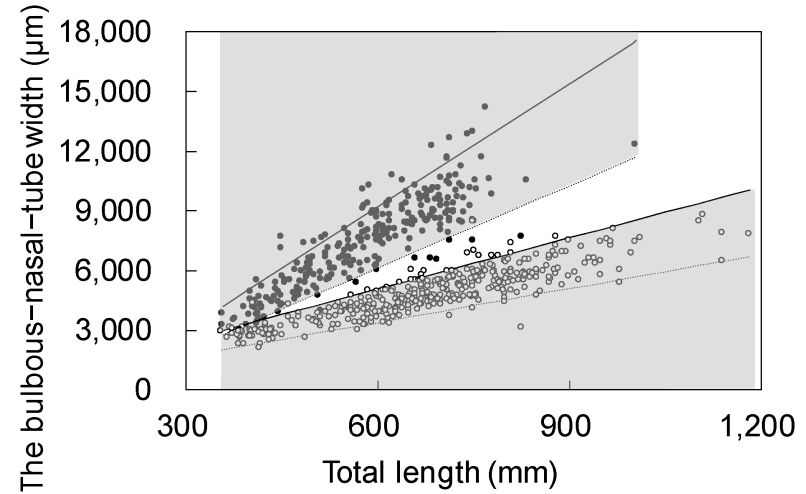

Fig. 2 Plot between total length and width of the bulbous nasal tubes of yellow goosefish Lophius litulon by individual. Open and filled circles indicate female and male individuals, respectively. Solid and dotted lines indicate $+20 \%$ and $-20 \%$ of both regression lines, respectively.

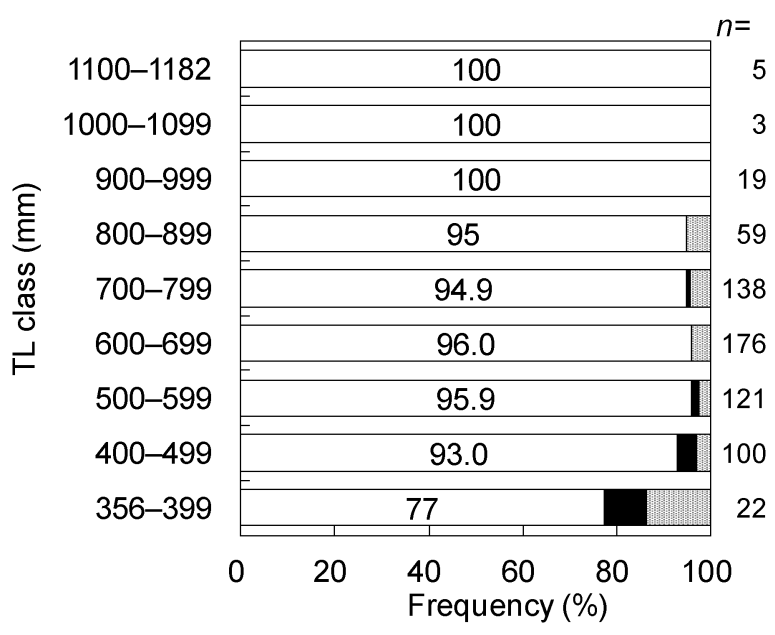

Fig. 3 Change in accuracy rate of sex determination by total length class using $\pm 20 \%$ of regression lines between total length and bulbous-nasal-tube width of yellow goosefish Lophius litulon by sex. White, black and gray bars indicate correct, wrong and unidentified rates, respectively. Numerals indicate sample sizes.

誤答率, 判別不能率は体長階級の増加によって有意に異 なり（体長階級の順序を考慮した比率の Kruskal-Wallis 検定 : $\left.K W^{\prime}=10.32, p=0.006\right)$, 大型になるにつれ て正答率が高くなり, 誤答率と性別不能の比率は低く なった。正答率は，356-399 mm TL で 77\% とやや低 かったものの，400-499 mm で 93.0\%，500-899 mm で 94.9-96.0\%， $\geq 900 \mathrm{~mm}$ で 100\%を示し，誤答個体は $800 \mathrm{~mm}$ 以上の階級ではみられなかった。以上よりこの 判別法は $400 \mathrm{~mm}$ TL 以上で $93 \%$ 以上の正答率を示す ほぼ実用的な性判別法であると考えられた。

市場に抢ける全長の測定と背鯺第一棘による年齢査 定3) と, 本研究における瘤状鼻管幅を用いた性判別を併 
せて実施すれば，試料魚を買い付け・解剖する必要な く, 購入費用を節約して, 成長解析や Age-length key の作成, 資源解析に大量のデータを供することができ, 本種の迅速な資源管理の実施への貢献が期待される。

Caruso ${ }^{8)}$ は, アンコウ科における瘤状鼻管の大きさは 性的二型であることを示唆しているが, 本研究で得られ た標本は雄が $357 \mathrm{~mm}$ TL 以上, 雌が $356 \mathrm{~mm}$ TL 以上 であり，東シナ海のデータではあるが $50 \%$ 成熟全長は 雄 $362 \mathrm{~mm}$ TL, 雌 $567 \mathrm{~mm}$ TL ${ }^{11)}$ が本研究海域でも同様 と仮定すると, 未成魚が雄 2 個体 $(0.8 \%)$, 雌 79 個体 (21.0\%) しかなく，どの成長段階から雌よりも雄の瘤 状鼻菅が大きくなるかを検証するには不十分であった。

一方, 津軽海峡では小型いか釣りの集魚灯に向かって海 面近くまで雌と考えられる大型のキアンコウ 1 個体が 浮上して来た際に, 複数の雄と考えられる小型のキアン コウが追尾して来た様子が観察されている（下風呂漁業 協同組合小型いか釣り漁業者私信)。また，津軽海峡に おけるキアンコウ刺網漁業では, 雌が羅網している箇所 を囲む様に, 複数の雄が羅網している様子がよく観察さ れる(蛇浦漁業協同組合沖刺網部会員私信)。水族館で は, 雌が産卵するために海面近くに浮上した後に, 雄が 追尾する様子が観察されている（(公財）ふくしま海洋 科学館・山内信弥, 松崎浩二, アクアワールド茨城県大 洗水族館魚類展示課・芝洋二郎, 柴垣和弘私信)。従っ て雄の大型の瘤状鼻管は, 産卵行動等に伴って, フェロ モンを発する雌を追尾するのに役立っているのかもしれ ない。今後は, 瘤状鼻管の大きさの性差が，成熟開始か ら生じるのかそれとも未成魚期から生じているのか, 未 成魚の標本を充実させて確認する必要がある。

\section{謝辞}

本稿の執筆にあたり, キアンコウ試料およびデータ等 を無償で提供下さった侏駒嶺商店の駒嶺岡一代表取締 役, 蛇浦漁業協同組合の山本公明業務主任, 同じく前田 稔主事補, 測定作業に協力頂いた地方独立行政法人青森 県産業技術センター水産総合研究所資源管理部員の諸 氏, 同じく下北ブランド研究所の諸氏, 有益な情報を御 提供頂いた下風呂漁業協同組合小型いか釣り漁業者諸 氏, 蛇浦漁業協同組合沖刺網部会員諸氏, (公財) 子くし
ま海洋科学館・山内信弥氏, 松崎浩二氏, アクアワール ド茨城県大洗水族館魚類展示課 - 芝洋二郎氏, 柴垣和弘 氏, 御助言頂いた国立研究開発法人水産研究・教育機構 瀬戸内海区水産研究所の米田道夫研究員, 地方独立行政 法人青森県産業技術センター水産総合研究所の野呂恭成 所長, 並びに查読者および担当編集委員の皆様に深く感 謝します。試料の一部は, 水産庁「我が国周辺水産資源 調査・評価推進事業」で得られた。

\section{文献}

1）野呂恭成, 竹谷裕平. 青森県沿岸におけるキアンコウの 漁獲状況と標識放流（その 2)。東北底魚研究 2009; 29: $2-6$.

2）竹谷裕平, 奈良賢靜, 小坂善信. バイオロギングによる キアンコウの行動解析. 水産技術 2013; 6: 1-15.

3) Takeya Y, Takatsu T, Yamanaka T, Shibata Y, Nakaya $\mathrm{M}$. Use of the illicium for age determination and verification of yellow goosefish Lophius litulon off Aomori Prefecture, northern Japan. Nippon Suisan Gakkaishi 2017; doi:10.2331/suisan.16-00041 (in Japanese with English abstract).

4) Yoneda M, Tokimura M, Fujita H, Takeshita N, Takeshita K. Matsuyama M, Matsuura S. Age and growth of anglerfish Lophius litulon in the East China Sea and the Yellow Sea. Fish. Sci. 1997; 63: 887-892.

5) 池川正人, 根本芳春, 安岡真司. 福島県海域のキアンコ ウの漁獲実態と生態について. 東北底魚研究 2000; 20: 29-35.

6）岩崎高資, 吉田哲也, 千代窪孝志, 佐藤美智男. 福島県 で水揚げされるキアンコウについて．福島県水産試験場 研究報告 $2010 ; 15:$ 11-25.

7）堀 義彦. 茨城県のキアンコウについて. 200 カイリ水 域内漁業資源総合調査, 第 14 回東北海区底魚研究チ么会議報告. 東北区水産研究所八戸支所，八戸。1993; 43-47.

8) Caruso JH. Sexual dimorphism of the olfactory organs of lophiids. Copeia 1975; 380-381.

9) Thangstad T, Dyb JE, Jónsson E, Laurenson C, Ofstad LH, Reeves SA. Anglerfish (Lophius spp.) in Nordic and European Waters: Status of current knowledge and ongoing research. Institute of Marine Research, Bergen. 2003.

10）足立堅一.「らくらく生物統計学」中山書店, 東京. 1998.

11) Yoneda $M$, Tokimura $M$, Fujita $H$, Takeshita $N$, Takeshita K, Matsuyama M, Matsuura S. Reproductive cycle, fecundity, and seasonal distribution of the anglerfish Lophius litulon in the East China and Yellow seas. Fish. Bull. 2001; 99: 356-356. 